\title{
A KÉPLETMONDÓKÁK MNEMOTECHNIKAI ALAPJAI AZ OXIPO-MODELL ASPEKTUSÁBÓL
}

\section{Szerzők:}

Mező Ferenc (PhD)

Eszterházy Károly Katolikus Egyetem
Lektorok:

\author{
Simó Ferenc Zoltán (Dr. Jur.) \\ Eszterházy Károly Katolikus Egyetem \\ Szabóné Balogh Ágota (Ph.D.) \\ Gál Ferenc Egyetem
}

Szerző e-mail címe:

ferenc.mezo1@gmail.com és további két anonim lektor...

\begin{abstract}
Absztrakt
A képletmondók egyfajta mnemotechnika, amely az algebrai kifejezések tanulására használható. Jelen tanulmány ezt a mnemotechnikát az OxIPO tanulási modell szemszögéből mutatja be. Kódolás esetén a mnemonikus bemenet egy képlet, a kimenet pedig egy mondóka erről a képletről. Visszakeresés, felidézés esetén a mnemonikus bemenet a képletmondóka, a kimenet pedig az eredeti képlet.
\end{abstract}

Kulcsszavak: mnemotechnika, tanulás, OxIPO

Diszciplína: pszichológia, pedagógia

\section{Abstract}

MNEMOTECHNIC BASICS OF POEMS ABOUT FORMULAS

FROM THE ASPECT OF THE OXIPO MODEL

The poems about formulas are a kind of mnemotechnics that can be used in the case of learning algebraic expressions. Present study show this mnemotechnic from the aspect of the OxIPO model of learning. In the case of encoding, the mnemonic input is a formula and the output is a poem about this formula. In the case of retrieving, recalling, the mnemonic input is the poem about the formula, and the output is the original formula.

Keywords: mnemotechnics, learning, OxIPO

Discipline: psychology, pedagogy

Mező Ferenc (2021): A képletmondókák mnemotechnikai alapjai az OxIPO-modell aspektusából. OxIPO - interdiszciplináris tudományos folyóirat, 2021/4, 17-30.

doi: 10.35405/OXIPO.2021.4.17 
A „mnemotechnika” összetett szó, amelynek első fele a görög eredetű „mnemo” „emlékezés”-t, „emlékezet”-et jelent (Mnémoszüné az emlékezés istennője volt a görög mitológiában), a „technika” pedig egyfajta módszertanra utal (a mnemotechnikák történetével kapcsolatban lásd: Yates, 2001). Ismert még „mnemonika” formában történő használata is (Yates, 1994). A „mnemotechnika”, „mnemonika" tehát az emlékezést segítő módszerekre utaló kifejezés - valójában gyűjtőszó, amivel igen változatos technikai repertoárra utalhatunk, amelyek túlmutatnak a megjegyzendő információ egyszerű recitálásán, ismételgetésén.

Az alábbiakban a „képletmondóka módszer"'-nek nevezett (Mező, 2011) mnemotechnikai módszer ismertetésére, OxIPO-séma szerinti elemzésére kerül sor. Mindezek előtt a tanulmány megértését minimálisan segítő alapismeretekre térünk ki mind a tanulás OxIPO-modellje, mind a mnemotechnikák aspektusából.

\section{Az OxIPO-modell alapfogalmai}

$\mathrm{Az}$ OxIPO-modell (Mező és Mező, 2019) szerint a tanulás egyfajta információfeldolgozási folyamat, amelynek főbb komponensei: a) az organizáció, ami meghatározó hatással van a további három komponensre, b) az input (fönévként: a tananyagra, igeként: az információbevitelre, melléknévként: az információbeviteli jellegre utaló kifejzés), c) a process (az információfeldolgozás), és d) az output (főnévként: felelet, dolgozat formájában vagy egyéb módon visszaadott információra; igeként: az információ-felhasználásra; melléknévként: az információkimeneti jellegre utaló kifejzés). A komponensek kezdőbetűi alkotják az OxIPO kifejezést (ahol az „x” az organizáció és a többi komponens közötti szorzati viszonyt jelöli).

A 2018 előtti forrásokban IPOO-modellként történt hivatkozás e tanulásmodellre (Mező, 2002). A névváltoztatás oka: 2018 előtt kizárólag tanulás módszertani célból volt használatban e modell, 2018 után azonban a tanulás módszertani kutatási irány kiegészült neurobiológiai, képesség-, személyiség- és mesterséges intelligencia kutatásra fókuszáló tevékenységgel is. Mindezeket a humán információfeldolgozás hatékonyságának növelését célzó OxIPO-projekt fogja össze napjainkban - elméleti, történeti, diagnosztikai és fejlesztési háttérinformációkat lásd Mező és Mező (2019) írásában.

Jelen tanulmány megértése szempontjából itt még mindössze annyit célszerű megemlíteni, hogy tanulás módszertani szempontból az OxIPO-projektben háromféle információ feldolgozási stratégiát különböztetünk meg az input és az output minőségi és mennyiségi jellemzőinek viszonya alapján:

1. Produktív (információt termelő) tanulás: input < output. Ez az OxIPO-projektben ideálisnak tekintett mód.

2. Reproduktív (megértés nélküli, magolva) tanulás: input $=$ output

3. Improduktív (információveszteséggel járó) tanulás: input $>$ output. 


\section{A mnemotechnikák föbb típusai}

Bármennyire is változatos a mnemotechnikák világa, lényegében három alapvető mechanizmus áll a hátterükben. A mnemotechnikák egy része a megjegyzendő ingerek szelektálásán alapul, másik része az ingerek átszerkesztésével segíti a bevésést és/vagy az előhívást, a harmadik fajtája pedig asszociációkon (képzettársításokon) keresztül fejti ki hatását. Ezek egymással kombinálva is alkalmazhatók.

Ingerszelekciós módszer például ,a kisebb csoport módszere": ha a tanulás lényege, hogy egy két csoportra osztható lista (ilyen a vízben vagy a zsírban oldódó vitaminok listája, vagy a magyar nyelvben a „," vagyz „ly” betűkkel írható madárnevek listája) kapcsán azt kell tudni, hogy a lista melyik eleme, melyik csoportba tartozik, akkor a kevesebb elemből álló listarészlet (például: a vízben oldódó $\mathrm{B}, \mathrm{C}, \mathrm{P}$ vitamin, vagy a „j”-vel írandó „héja, papagáj, varjú, fürj, szajkó" madárnevek) megjegyzésével kizárásos alapon azt is tudjuk, hogy mi tartozik a másik listarészletbe (az összes többi vitamin zsírban oldódik, illetve a többi ,jé" hangot tartalmazó madárnév „ly”-nal írandó).

A mnemotechnikák egy másik típusa a megjegyzendő információ átszerkesztésével segíti az emlékezést. Legtipikusabb példaként a tömbösités módszere hozható fel ezzel kapcsolatban: szám- vagy betüsorozatot nem elemenként, hanem 2-5 elemű csoportonként jegyzünk meg. Ez történik, ha egy telefonszámot nem szám- jegyenként, hanem két-három számjegyből álló számcsoportonként jegyzünk meg.

A menmotechnikák harmadik típusa asszociációs alapon nyugszik, és talán Walter Kugemann (1976) „ruhaszárító” metaforája írja le legegyszerűbben, leghétköznapibb és legközérthetőbb módon a múködésüket (1. ábra).

1. ábra: Kugemann (1976) „ruhasqaírtó metaforájának" szemléltetése. A számok jelentése: 1) "lepedö” = új információ, 2) „ruhaszárító kötél” = korábbi emlékeke, 3) „csipeszelk” = aszszociációk a korábbi emlékek és az új infomrció között. Forrás: a Szerzó

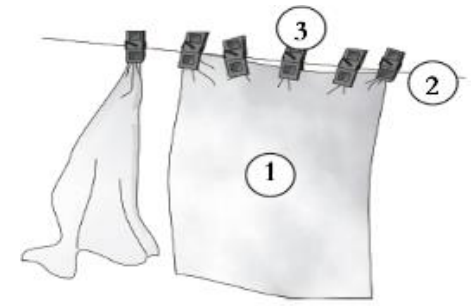

„Kugemann (1976, 210-211. o.) által közölt »ruhaszárító metafora« lényege: „Hogyan aggat fel a háziasszony a szárítókötélre egy frissen mosott, súlyos lepedőt? Talán egyetlen csíptetővel (...)? Szó sincs róla. Nagyon bizonytalan lenne, joggal félne attól, hogy a lepedő előbb-utóbb leesik. Ehelyett jó sűrűn, egymáshoz közel elhelyezett csíptetőkkel fogja hozzá a kötélhez. Így még akkor is, ha néhány csíptető alól ki is csúszna a lepedő, a többiek 
még megtarthatják. Ezenfelül jobban is szárad, egész felülete kifeszül. Így vagyunk a tanulással is. Súlyos hiba, ha egy dolgot csak egyetlen csíptetővel - egyetlen asszociációval - rögzítünk emlékezetünkben. Így nagy a veszélye, hogy a kapcsolat megszakad: túl keskeny a gondolathoz vezető ösvény. Ezért bármit tanuljunk is, azt annyi helyen kell kapoccsal rögzítenünk, ahányon csak lehet. Az ilyen »sok csípesszel« biztosított tudás jóval rugalmasabb is."

Néhány példa az asszociáción alapuló mnemotechnikákra:

Hasonló hangzás módszere. Az új információt egy már ismert, hasonló hangzású szóhoz asszociáljuk a memorizálás során. Példa: a „bariton” szó megjegyzése a „barnítom” szó segítségével.

Helyhez kötés módszere. A megjegyzendő információt ismert helyszín tereptárgyaihoz kötve memorizáljuk. Példa: a saját szoba bútoraihoz kötjük a megjegyzendő lista tételeit, s felidézéskor képzeletben körbefordulunk a szobában.

Mondatbaszövés vagy történetbeszövés módszere. A megjegyzendő információt (kevés megjegyzendő elem esetén) egy mondatba vagy (sok elem esetén) egy történetbe szőve memorizáljuk, s idézzük fel. Példa: „»Hejj! Ott repül a papagáj!« Mondja a fürj a szajkónak meg a varjúnak." mondatból felidézhetők a j-betűvel írandó madárnevek: héja, papagáj, fürj, szajkó, varjú. E példa azt is szemlélteti, hogy a mnemotechnikai módszerek valóban kombinál- hatók egyással: a példában a történetbeszövés módszerét segítette a hasonló hangzás módszere (a „Hejj!” kifejezés utalt a „héja” szóra).

Bizarság módszere. A nehezen megjegyezhetô és/vagy nem kedvelt tananyag memorizálását segíti, ha bizar képbe vagy történetbe ágyazzuk azt. Példa: az előbbi madárnevekhez kötődő mnemotechnikai mondat bizarabb verziója így is hangozhat: „»Hejj! Ott repül a papagáj!« Mondja az a hülye fürj annak a szarjankó varjúnak." Amellett, hogy a hasonló hangzás módszerét itt is láthatjuk, a példa azt is szemléleteti, hogy a memorizálást akár nyomdafestéket kevésbé tűrő kifejezések is segíthetik, mivel biztosítanak egyfajta bizarságot.

Mozaikszó, mozaikmondat módszere. megtanulandó lista elemeinek kezdőbetűiből (vagy: első szótagjaiból) egy többé-kevésbé értelmes szót hozunk létre (például: „IPOO” szót az input, process, output, organizáció szavakból), vagy olyan mondatot alkotunk, ami szavainak kezdőbetűi vagy szótagjai utalnak a lista elemeire (például: „Ici-pici oroszlán orrlyuka" = „IPOO” = input, process, output, organizáció).

Szám-szimbólum módszer. Számok megjegyzését segítő vizualizációs módszer, ha a 0-9 számjegyekhez írásképükhöz és/ vagy hangzásukhoz kapcsolódó szimbólumokat kapcsolunk, és a képet is memorizáljuk. Példa: $0=$ labda, $1=$ rúd, $2=$ hattyú, 3 = madár, $4=$ vitorláshajó, $5=$ fogas, $6=$ füllbevaló, $7=$ nyíl, $8=$ hóember, 9 = kukac. „2021” = „hattyú- 
labda-hattyú-rúd” = „a hattyú labdát dob a másik hattyúnak a rúdhoz", s ez persze képként is vizualizálható.

Megzenésités módszere. A megjegyzendő információkhoz dallamot is társíthatunk, s így kvázi dalszöveggé alakíthatjuk azt.

Vizualizáció módszere. A megjegyzendő információhoz ábrát (garfikát vagy akár digramot, gráf-ábrát stb.) csatolunk.

Képletmondóka módszer. Algebrai képletek memorizálását (bevésését és felidézését) mondókák segítségével segítő módszer. A tanulmány további részében erről lesz szó részletesen.

\section{A képletmondóka módszer}

A képletmondóka algebrai kifejezések memóriába történő bevésését és memóriából történő előhívását segítő mondóka.

\section{Példák:}

1. képlet: a normált másodfokú egyenlet $\left(\mathrm{x}^{2}+\mathrm{px}+\mathrm{q}=0\right)$ Viète-formulát alkalmazó megoldó képlete:

$$
x=\frac{-p \pm \sqrt{p^{2}-4 q}}{2}
$$

Kimondva: „Iksz egyenlő mínusz pé plusz-mínusz négyzetgyök alatt pé-négyzet mínusz négy kú per kettő”.

Képletmondóka (szerző: Mező Ferenc, forrás: Mező, Mező és Mező, 2015, 63. o.): „Nem piros plüss, nem gyökér, pipből négy mázsa, s mindezek fele X-et ér." V.ö.: 2. ábra.
2. képlet: a függőlegesen felfelé hajított test sebességének kiszámolásához használható képlet:

$$
V_{t}=\sqrt{V_{0}^{2}-2 g s}
$$

Kimondva: „Vé-té egyenlő négyzetgyök alatt vé-null a négyzeten mínusz két gészer es".

Képletmondóka (szerző: Mező Ferenc, forrás: Mező, Mező és Mező, 2015, 64. o.): „Vét az, aki gyökérkezelés alatt mások hintaágyán vénül - kétség nélkül”.

Megjegyzések: 1) „mások hintaágyán” = második hatvány, 2) „kétség” = 2sg = 2gs vagyis kihasználtuk, hogy a szorzat tagjai átrendezhetők ( $2 \mathrm{gs}=2 \mathrm{sg})$, így a „kétség” szó a „2sg” jelhármashoz rendelhető; 3) „,kétség nélkül” = „,-2sg” esetében a magyar nyelv megengedi, hogy a kivonásra utaló „nélkül” szót a kivonandó (a „2sg”) után helyezzük el a mondókába, s ne elé, ahogy az eredeti képletben van és matematikai jelölés szerint helyes (,,-2sg”).

Egy képlet - például a másodfokú egyenletek megoldóképlete - legalább háromféle módon, illetve e módszerek kombinációjával jegyezhető meg. Rögzíthetô vizuális információként (szélsőségesen vizuális tanulási stílusú, illetve a fotografikus memóriával rendelkezők esetében ez lehet az elsődleges mód) és/vagy a képlet hangos vagy néma felolvasásakor keletkező szemantikus információként és/vagy a képlethez kapcsolódó mondóka segítsé- 
2. ábra: képletmondókát bemutató példa. Forrás: a Szerzọ

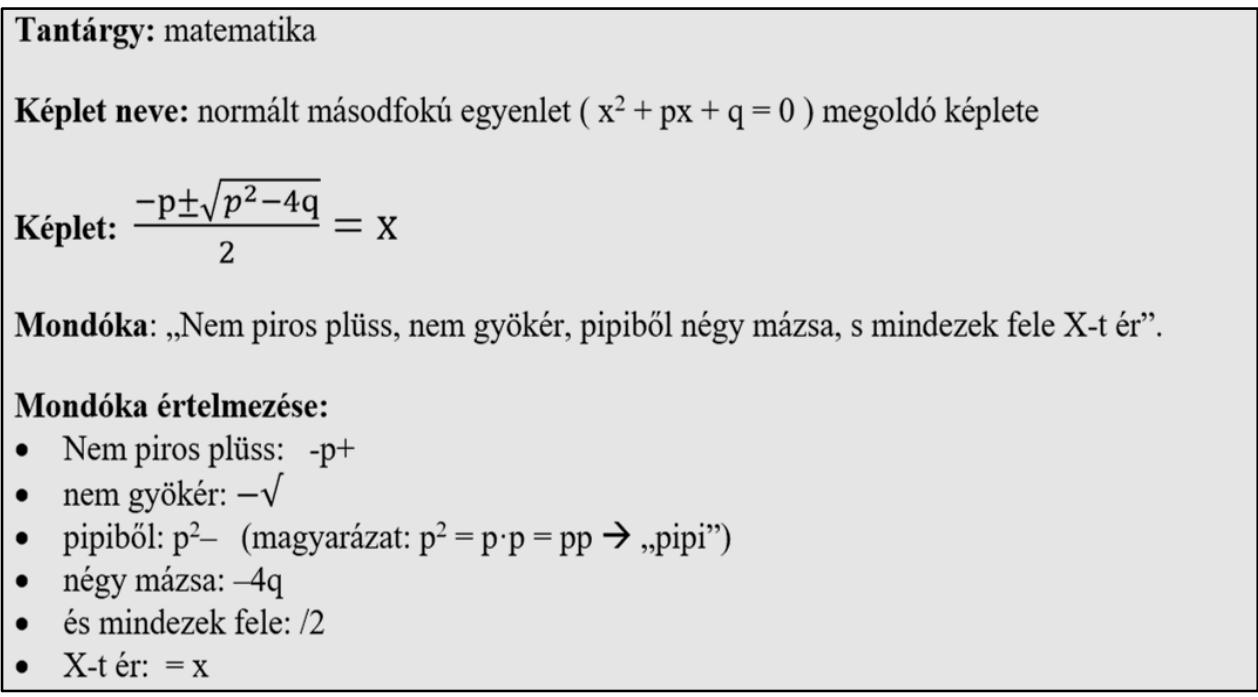

gével (ez szintén szemantikus információként kerül tárolásra). Részletesebben:

Tegyük fel, hogy a normált másodfokú egyenlet $\left(\mathrm{x}^{2}+\mathrm{px}+\mathrm{q}=0\right)$ Viète-formulát alkalmazó megoldó képletét kell egy tanúlónak memorizálnia. Ebben az esetben az input:

$$
X=\frac{-p \pm \sqrt{p^{2}-4 q}}{2}
$$

A képlet felidézésekor (az output) során adódó lehetőségek:

1. Vizuális rögzítés esetében a tanuló által felidézett vizuális információ ez lesz:

$$
X=\frac{-p \pm \sqrt{p^{2}-4 q}}{2}
$$

2. A képlet hangos vagy néma felolvasásásával, ismételgetésével járó szemantikus rögzítés esetében a tanuló által feli- dézett információ: „Iksz egyenlő mínusz pé plusz-mínusz négyzetgyök alatt pénégyzet mínusz négy kú per kettő”, ami leírva:

$$
X=\frac{-p \pm \sqrt{p^{2}-4 q}}{2}
$$

3. Képletmondókával történt szemantikus rögzítés esetében a tanuló által felidézett információ: „Nem piros plüss, nem gyökér, pipből négy mázsa, s mindezek fele X-et ér.”, ami azt jelenti, hogy (v.ö.: 2. ábra):

$$
x=\frac{-p \pm \sqrt{p^{2}-4 q}}{2}
$$

\section{Lehetőség: a fentiek kombínációja.}

A képletmondóka módszer azoknak segíthet, akikre jellemző, hogy: 
a) algebrai kifejezéseket kell megtanulniuk;

b) nem vizuálizálva tanulnak képleteket (különösen: nem rendelkeznek fotografikus emlékezettel);

c) az elvont algebrai kifjezések felolvasásszerű recitálását nehéznek és/vagy unalmasnak tartják;

d) a mondókák (esetleg dalszövegek) tanulásában sikeresek.

A képletmondóka alkalmazása az információfeldolgozás minimum három lépését feltételezi (3. ábra):

1. lépés: elōkészités, a megjegyzendő információ átszerkesztése (az algebrai kifejezésből mondóka alkotása). Mnemotechnikai input: képlet, output: mondóka.

Megjegyzés: a tanulásszervezés (organizáció) szempontjából a képletmondókát előállíthatja maga a tanuló, vagy készen kaphatja azt (tanártól, kortárstól, szakirodalomból, stb.). Amikor maga a tanuló állítja elő a képletmondókát, az produktív tanulást (input < output) jelent az ő szempontjából. Amikor „készen” kapott mondókát tanul meg, akkor azonban reproduktív tanulásról (input $=$ output) beszélhetünk (kivéve, ha meg is érti a képlet mondókába kódolt összefüggéseit, mert ez már produktív tanúlásnak minősül).

2. lépés: bevésés, tárolás. Az 1. lépés eredményeként létrejövő mondóka memorizálása az algebrai kifejezés képi és/vagy
3. ábra: a képletmondóka révén történö memorizálás az információfeldolgozás minimum három lépését feltételezi. Forrás: a Szerzọ"

\section{Előkészítés:*}

\begin{tabular}{c|l} 
Input: & képlet \\
Process: & $\begin{array}{l}\boldsymbol{\Downarrow} \text { átszerkesztés } \\
\text { mondóka }\end{array}$
\end{tabular}

2. Bevésés, tárolás:

$\begin{array}{cl}\text { Input: } & \begin{array}{l}\text { mondóka+képlet } \\ \text { Process: } \\ \text { Output: }\end{array} \quad \begin{array}{l}\boldsymbol{\Downarrow} \text { ismétlés } \\ \text { mondóka+képlet }\end{array}\end{array}$

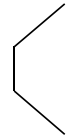

3. Előhívás:

\begin{tabular}{c|l} 
Input: \\
Process: \\
Output:
\end{tabular}

*Tanulásszervezési (organizációs) szempontból a képletmondókát létrehozhatja a tanuló személy, vagy készen kaphatja azt másoktól

szemantikus reprezentációjával együtt. Mnemotechnikai input: képlet és/vagy mondóka, output: emlék a képlet/mondóka egységről.

A bevésés és az előhívás közötti időszakban történik meg az emlékek tárolása. A tárolást a pszichológiai szakirodalom külön memorizálási fázisként szokta kezelni. Esetünkben egyrészt nem feltételezünk lényeges különbséget az információk bevésési és tárolási modalitása között, másrészt a tárolást a bevésséhez és előhíváshoz képest egy viszonylag passzív folyamatnak tekinthetjük, amiről kevés 
objektív infomrációt tudunk közölni. Így jobb híján a bevéséssel együtt közli a tárolással kapcsolatos jelenségeket a 3 . ábra.

3. lépés: elóhivás. A képletmondóka segítségével a képlet felidézése. Mnemotechnikai input: képletmondóka, output: képlet.

A továbbiakban képletmondókák létrehozását segítő javaslatokat mutatunk be.

\section{Segédlet}

\section{képletmondókák alkotásához}

Segítheti ugyan a tanulást, ha a tanuló készen kap egy képletmondókát, ám ez esetben még mindig csak reproduktív tanulást folytat a diák, másrészt nem „küzd” meg a képletmondóka alkotásának kreatív problémájával. Ha a diák saját maga hoz létre képletmondókát, akkor azonban nem csak információtermelés, produktum (a képletmondóka) jön létre, hanem a képletmondóka alkotása közben is megtörténhet a képlet bevésése a memóriába.

Az alábbiakban a képletmondókák alkotásával kapcsolatos néhány javaslat összefoglalására kerül sor.

\section{Matematikai szimbólumok szótára}

A képletekben gyakran előforduló matematikai szimbólumokhoz (péládul: +,-, *, /, V, stb.) a képletmondókában felhasználható kifejezéseket rendelhetünk, s az így összeállt „szótár” segtíhet az új képletmondókák létehozása esetében. A matematikai szimbólumokhoz rendelt kifejezések vonatkozhatnak a jel kiejtésére (például: + = „plusz”), a jel kiejtéséhez hasonló hangzású szóra (például: $+=$ „plüss”), a jel írásképe alapján létrehozott asszociációra (például: $+=$,kereszt, sírkereszt, sír”). Például:

+: meg, még, és, plusz, plüss, kereszt, temető, stb.

-: ne, nem, se, sem, mínusz, negatív, nélkül, nélkülözés, -ból/-ből, -talan/ -telen, un-, a-, anti-, de-, no, csík, stb.

\pm : plusz-mínusz, meg se, meg sem, mégse, mégsem, stb. Megjegyzés: a két külön jelre osztható szimbólumok (például: \pm ) részei (például: a + és -) külön is megjelenhetnek a képletmondókákban.

$\sqrt{ }$ : (négyzet)gyök, (négyzet)gyök alatt, gyökér, gyökeres, gyökérkezelés, stb.

A matematikai szimbólumokat tartalmazó szótár tovább gazdagodhat, ha idegen nyelvből származó szavakat is be tudunk vonni. Például a „,-" szimbólumhoz a magyar „nem” szón kívül társíthatjuk a latin, angol, olasz, spanyol nyelvben is ismert „no”, a francia „non”, a német „nicht” vagy „nein”, a kínai „bú”, a japán „ie”, az orosz „nyet”, az eszperantó „ne”, a román „nu”, vagy akár a zulu „cha” stb. szavakat - de ez csak akkor segít, ha emlékszünk e szavak jelentésére.

A matematikai operátorokon túl egyéb gyakori változók, állandók nevével kapcsolatban is összeállítható képletmondóka alkotást segítő szólista. Például:

$\alpha$ : alfa, álfa, vállfa, talpfa, alja fa, alfahím, alfaj, halfaj, stb.

$\beta$ : béta, buta, béka, Béla, stb.

$\pi$ : pí, pír, pírkad(at), piros, pionír, stb. 


\section{Képletek áttrendezése}

Esetenként előfordulhat, hogy a képlet eredeti alakjához képest egyszerúbb mondóka-részleteket kitalálni a képlet valamely transzformációjához. Ilyen esetben a képlet átszerkesztése segítheti a mondóka alkotását. Példák három változót tartalmazó képletek átalakítására:

$\mathrm{A} z \mathrm{a}=\mathrm{b}+\mathrm{c}$ képlet átalakítható a következő változatokra például:

$$
\begin{aligned}
& b+c=a \\
& b=a-c \\
& a-c=b \\
& c=a-b \\
& a-b=c .
\end{aligned}
$$

Ha e képletet háromból két változót tartalmazóra alakítjuk, akkor ezek a változatok is rendelkezésünkre állhatnak: $\mathrm{a}=(\mathrm{a}$ $-c)+c,(a-c)+c=a, c=a-(a-c), a$ $-(\mathrm{a}-\mathrm{c})=\mathrm{c}, \mathrm{a}=\mathrm{b}+(\mathrm{a}-\mathrm{b}), \mathrm{b}+(\mathrm{a}-\mathrm{b})$ $=\mathrm{a}, \mathrm{stb}$.

$\mathrm{Az} a=\mathrm{b}$ x c felépítésű képlet átalakítható például az alábbi változatokra:

$\mathrm{b} \times \mathrm{c}=\mathrm{a}$

$\mathrm{b}=\mathrm{a} / \mathrm{c}$

$\mathrm{a} / \mathrm{c}=\mathrm{b}$

$\mathrm{c}=\mathrm{a} / \mathrm{b}$

$\mathrm{a} / \mathrm{b}=\mathrm{c}$.

A szorzást, osztást tartalmazó képletek átrendezését segíti a „,szamár háromszögként" ismert, az átrendezés vizualizálását segítő ábra (4. ábra).

Természetesen ilyen esetben is élhetünk a háromból kétváltozós formába alakítás lehetőségével - például: $\mathrm{a}=\mathrm{b}$ x c jelentése azonos az a $=(\mathrm{a} / \mathrm{c}) \mathrm{x}$ c verzióval, stb.
4. ábra: a „szamár háromszög"-ként ismert ábra. Forrás: ismeretlen forrás alapján a Szerzo"

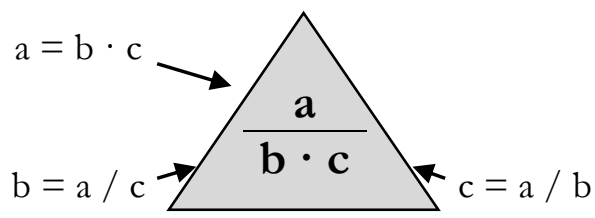

Kihasználhatjuk továbbá azt is, hogy a szorzás disztributív az összeadásra és a kivonásra tekintve, vagyis: $\mathrm{a}(\mathrm{b}+\mathrm{c})=\mathrm{ab}+$ ac.

\section{Ritmus, rím, szótagszám}

A képletmondóka használatát segíti, ha ritmusa, belső vagy sorvégi rímei alapján könyebben megjegyezhető (1. táblázat).

A ritmus és a rímek esetében persze megköti az alkotó kezét, hogy hány eleme van, illetve hány elemre bontható a képletmondóka, és milyen hívószavakat sikerült találni hozzá. Így előfordul, hogy a képletmondókánkra kínrímek (erőltetett szójátékon alapuló rímek) lesznek jellemzők, vagy: egyáltalán nem fog rímet tartalmazni.

Megjegyezzük azonban, hogy: a képletmondókáknak nem szükséges a legnemesebb értelemben vett irodalomművészeti alkotásoknak lenniük! Így - ha betöltik céljukat: az algebrai kifejezések memorizálásának segítését - az sem baj, ha irodalmi szempontból esetlenek, ügyetlenek. 
1. táblázat: képletmondókák elemzése rím és szótagszám alapján. Forrás: a Szerzó

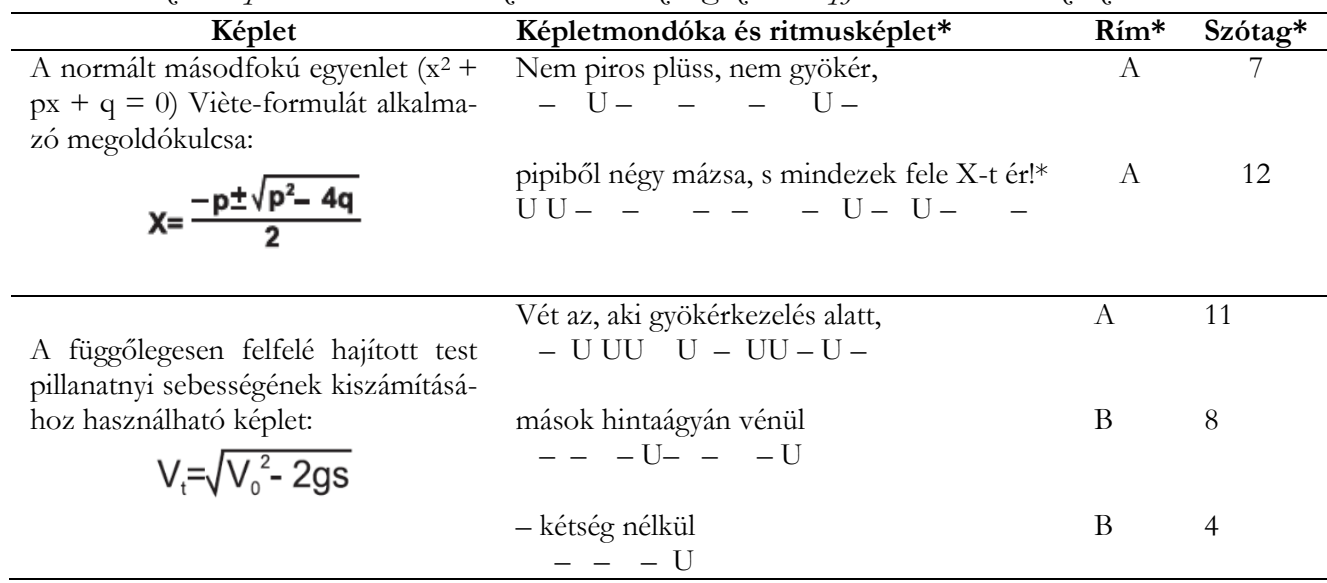

*Ritmusképlet, rím és szótagszám online verselemző szoftverrel lett előállítva. Forrása: Net

Megjegyzés: A hosszú szótag jele az elemzési képletben: -

A rövid szótag jele: $U$

A közömbös vagy helyettesítő szótag jele: $U$ vagy x (a szakirodalomban még: 0 )

$A z$ 1. táblázatban látható arra vonatkozó példa, hogy az „és” kötőszó „s” változatának alkalmazása egyrészt módosíthatja a ritmusképletet, másrészt alkalmazható konvenció lehet arra, hogy az „és” szót az összeadásra utaló kifejezésként használjuk a képletmondókákban, míg a "s" jelölést alkalmazhatjuk szavak, tagmondatokközötti mellérendelő kapcsolatot kifejező kötőszóként.

A képletmondókák alkotásában segítséget nyújthatnak az alábbi, a poet.hu oldalról ingyenesen elérhető online alkalmazások, tartalmak:

- Verselemzés: Net1,

- Rímszótár: Net2,

- Versszerkesztő (használatakor a sorok ritmusképlete és szótagszáma szerkesztés közben folyamatosan látható).

Net3,
- Szinonimaszótár: Net4,

- Ellentétszótár: Net5,

- Verstani lexikon: Net6.

\section{Képletmondókák kombinálása}

más mnemotechnikákekal

A képletmondókák önmagukban is hasznos segítséget jelenthetnek az algebrai kifejezések memorizálása során, azonban lehetőség van arra, hogy egyéb mnemotechnikákkal kombináltan alkalmazzuk azokat. Lássunk néhány példát!

A basonló hangzás módszerét hasznosítjuk például, amikor a gyakori matematikai szimbólumokkal kapcsolatos szótárt hozunk létre (lásd fentebb), illetve a szimbólumok hangalakjához hasonló szavakat használunk a képletmondókákban. Példa: „alfa” $\rightarrow$,talpfa”, ,plusz” $\rightarrow$,plüss” stb. 
A helyzhez kötés módszere színezheti a képletmondókáinkat: ismert vagy elképzelt helyszín tereptárgyaihoz is köthetjük a megjegyzendő képlet részleteit. Például: „X $=2 \mathrm{a}-\mathrm{INT}(\beta)$ ” $\rightarrow$,Tábla jelzi a sínt, ami után páratlan béka int”, ahol: „X=” a vasúti kereszteződést jelző tábla és a sín a mondókában, ,2a-” = páratlan, , INT $(\beta)$ ” $=$,béka int”. A helyhez kötés módszerét sajátos módon ötvözhetjük a térszemléletet fejlesztô egyéb módszertanokkal is (Beták és Szabó, 2020), akár mesterségesen létrehozott tanulóterek, modellek, virtuális helyszínek építése, alkalmazása révén is.

A képletmondókák a mondatba-, történetbeszövés módszerének képletekere vonatkoztatot esetének is tekitnhetők (az előkészítés során ugyanis az input: képlet; az output: mondatba, esetleg történetbe szôt képletmondóka).

A bizarság módszerével is kombinálható a képletmondóka alkotás, használat. A bizarság megjelenhet a matematikai szimbólumokhoz rendelt hívószavak szintjén (például: „szorozva” helyett a „szarozva” szó alkalmazásával), vagy a mondóka egésze által megjelenített kontextus, történet szintjén (v.ö.: a függőlegesen felfelé hajított test pillanatnyi sebességének kiszámításához használható képlethez javasolt és fentebb már közölt mondókát).

A képletmondókák szoros kapcsolatban állnak a mozaikszavakon, mozaikmondatokon alapuló mnemotechnikával. Ennek oka, hogy a képletmondóka lényegében a mozaikmondat módszer speciális esetének tekinthetô: a felolvasott képlet szavaihoz rendelünk olyan mondatot, amely szavainak kezdőbetűi, esetleg szótagjai utalnak az adott szavakra. Olyan esetben, amikor a képlet kettő vagy több szimbólumára egyetlen szóval utalunk a képletmondókában (például: a korábbi példában szereplő „2sg” szimbólumcsoportra a „kétség” szóval utaltunk), akkor mozaikszót használunk a képletmondókán belül.

A szám-szimbólum módszer is kombinálható a képletmondóka módszerrel, ha a megjegyzendő képlet konkrét számokat is tartalmaz. Ilyenkor nemcsak a számhoz rendelt szimbólum vizualizációja (például a kettes szám írásképhez kapcsolódó hatytyú képének felidézése) segíthet, hanem a szimbólum hangalakja (például: a kimondott „hattyú” szó) szemantikusan illeszkedhet a képletünkbe: Például: „2+” = „hattyú halála” - megjegyzés: a kettes írásképe hasonlít a hattyúhoz, aminek hangalakja: „hattyú”; a „," jel utalhat temetőre, ami asszociálódik a halálhoz.

A megzenésités módszere háromféle módon is kapcsolódhat a képletmondókák módszeréhez. Egyrészt önálló dallam komponálható egy képletmondókához, másrészt már létező dallamra „énekelhető fel” a képletmondóka. Végül: egy képletmondóka vagy részlete utalhat már ismert zeneműre, így a zenemű dallamának felidézése hívóinger lehet a képletmondóka(részlet) felidézéséhez. Az előző példánál maradva: a „2+" képletmondóka részlethez társított „hattyú halála” kifejezéshez kapcsolódhat, ami Charles Camille Saint-Saëns által komponált zene (lásd: Az állatok farsangja 
- zoológiai fantázia No.13 - A hatytyú) felidézését is segitheti, s viszont.

A vizualizáció módszere is támogathatja a képletmondókák alakalmazását. Egyrészt a vizualizálható maga a képlet írásképe, másrészt vizualizálható a képlet vagy részlete valamilyen grafikához társítva (például a már említett „2"'-es számhoz társítva elképzelhetünk egy hattyút, a „2+" szimbólumcsoporthoz társított a „hattyú halála” kódhoz pedig elképzelhetünk egy madártetemet - ami ráadásul a bizarsága miatt is segítheti a felidézést. Végül: fennköltebb hozzáállást és művészeti háttérismereteket is feltételezve a „hattyú halála” kapcsán felidézhetjük a hattyú halála tánckölteményt, mely Anna Pavlova (1881-1931) balerina leghíresebb szerepe volt (Mihail Fokin „A hattyú halála” című szóló tánckölteményt az ő számára koreografálta Charles Camille Saint-Saëns zenéjére „Az állatok farsangja" című múben).

Látható tehát, hogy a képletmondókák módszere más mnemotechnikákkal összevontan is alkalmazható eljárás.

\section{Zárógondolatok}

Képletek, formulák, algebrai kfijezések napjainkban jóformán minden diszciplina tan- és szakanyagában megjelenhet, ami egyben azt is jelenti, hogy minden tagozat, specializáció, szak, kutatási terület tanulója, hallgatója, oktatója, kutatója találkozik képletekkel, s olykor azok megjegyzésének problémájával. E probléma megelőzésére, kezelésre használható mnemotechnikai módszer a képletmondókák alkalmazása.
A képletmondókák speciálisan az algebrai kifejezések memorizálást segítő mnemotechnikai eszközök. Lényegében hídat képeznek a matematikai és a nyelvi szimbólumrendszer között. Lehetőséget adnak arra, hogy ne csak szépirodalmi és történelmi (Bárczi, 2020), hanem tanulásmódszertani kontextusban is új irodalmi koncepció jelenjen meg. A képletmondókák azon túl, hogy alkalmasak a matematika és a nyelv, az irodalom közötti kapcsolatteremtésre, hasznosíthatók a tanulói érdeklődés felkeltésére (v.ö.: Nagy Lehocky, 2008), tehetséggondozó programokban (Pšenáková és Nagyová Lehocká, 2011), élménypedagógiai foglalkozásokon (lásd: Mező Katalin, 2015) történő alkalmazásra, s kiegészíthetik a kognitív képességek fejlesztését (Szabóné Balogh, 2020) és azok matematikai kontextusban történő ápolását (lásd például: Tóth és tsai, 2021, Nagyová Lehocká, 2020, Nagyová Lehocká és Csáky 2020; Nagyová Lehocká, Csáky és Žitný, 2021) célzó törekvéseket is.

Mindent összevetve: a képletmondókák hasznos eszközei lehetnek a humán információfeldolgozás hatékonyságának növelését célzó OxIPO-projekten alapuló oktatásnak, produktív (információt termelő) tanulásnak.

\section{Irodalom}

Bárczi, Zsófia (2020): Attempts at creating a new concept of literature (The Hungarian literature in Slovakia between the two world wars). 
Hungarian Studies, 34 (2020) 1, 7-14. Doi: $10.1556 / 044.2020 .00002$

Beták Norbert és Szabó Tibor (2020). Térszemlélet-fejlesztést segítő foglalkozások Lego eszközök segítségével. OxIPO - interdiszciplináris tudományos folyoirat, 2020/4, 71-81. doi: 10.35405/OXIPO.2020.4.71

Kugemann, Walter (1976): Megtanulok tanulni. Gondolat Kiadó, Budapest

Mező Ferenc (2002): A tanulás stratégiája. Pedellus Novitas Tankönyvkiadó,Debrecen.

Mező Ferenc (2011): Tanulás: diagnosztikea és fejlesztés az IPOO-modell alapján. $\mathrm{K}+\mathrm{F}$ Stúdió Kft., Debrecen.

Mező Ferenc és Mező Katalin (2019): Az OxIPO-modell - az interdiszciplináris kutatások egy lehetséges értelmezési kerete. OxIPO - interdiszciplináris tudományos folyóirat, 2019/1, 9-21. doi: 10.35405/OXIPO.2019.1.9

Mező Ferenc, Mező Katalin és Mező Lilla Dóra (2015): Tanulógép - Tanulás módszertani javaslatok. $\mathrm{K}+\mathrm{F}$ Stúdió Kft., Debrecen.

Mező Katalin (2015): Kreativitás és élménypedagógia. Kocka Kör, Debrecen.

Nagy Lehocky Zsuzsa (2008): A tanulói érdéklődés felkeltésének fontossága. In: Bárczi Zsófia, Psenák Ildikó és Vančo Ildikó (szerk.): Képzés és gyakorlat $=$ Edukácia a prax (tanulmánykötet). Nitra: UKF. 33-37. ISBN 978-80-8094-427-8

Nagyová Lehocká, Zuzana (2020): Manipulációs eszközök a matematikaórán. Katedra - Szlovákiai magyar pedagógusok és szülók lapja. Roč. 28, č. 2 (2020), s. 2627.

Nagyová Lehocká, Z. és Csáky A. (2020): A térlátás fejlesztését segítő térbeli eszközök. In Katedra - Szlovákiai magyar pedagógusok és sqülók lapja. Roč. 28, č. 3 (2020), s. 28-29.

Nagyová Lehocká, Z., Csáky, A. \& Žitný, R. (2021): Best practices for improving spatial imagination in mathematics, AD ALTA. Journal of interdisciplinary research, 2021, ROČ.11/ Č.01

Net1: Online verselemző. Letöltés: 2021.

12.10. Web:

https://www.poet.hu/verselemzo.php Net2: Online rímszótár. Letöltés: 2021.12.

10. Web: https://rimszotar.poet.hu/

Net3: Online versszerkesztő: Letöltés:

2021.12.10. Web:

https://www.poet.hu/versszerkeszto. php

Net4: Online szinonimaszótár. Letöltés:

2021.12.10. Web:

https://szinonimaszotar.poet.hu/

Net5: Online ellentétszótár. Letöltés:

2021.12.10. Web:

https://ellentetszotar.hu/

Net6: Verstani lexikon. Letöltés: 2021.12.

10. Web:

http://enciklopedia.fazekas.hu/versta

n/Bokorrim_halmazrim.htm

Pšenáková, Ildikó és Nagyová Lehocká, Zuzana (2011): A tehetséggondozás korlátok nélkül. In: $A$ tehetséges tanulókekak való munka módszertana - The methodology of working with talented pupils : Az. Újvidéki Egyetem Magyar Tannyelvú Tanitóképzó Kara V. nemzetközi tudomá- 
nyos konferenciájának elöadásai, Szabadka, 2011. november 3-5. - Subotica : Újvidéki Egyetem, Magyar Tannyelvü Tanítóképző Kar, Szabadka, 2011. ISBN 978-86-87095-17-5, s. 44-50

Szabóné Balogh Ágota (2020): Kognitív képességek informatikai alapú fejlesztésének hatásvizsgálata 5-8. évfolyamon tanulók körében. OxIPO - interdiszciplináris tudományos folyóirat, 2020/4, 41-58. doi: 10.35405/OXIPO.2020.4.41
Tóth Attila, Nagy Lehocky Zsuzsa, Csáky Antal és Sedlák Margaréta (2021): Geometriai vizualizáció a gyakorlatban. OxIPO - interdiszciplináris tudományos folyóirat, 2021/1, 83-95. doi: 10.35405/OXIPO.2021.1.83

Yates, Francis A. (1994): Gedächtnis und Erinnern. Mnemonik von Aristoteles bis Shakespeare. 3. Auflage. Berlin: Akademie Verlag, ISBN 978-3-05002617-6.

Yates, Francis A. (2001): The Art of Memory. Chicago: The University of Chicago Press. ISBN 9780226950013. 